\title{
Understanding Consumers' Attitudes and Behavioural Intentions towards Corporate Social Responsibility in the Airline Industry: The Role of Perceived Value and Expectations
}

\author{
Kleopatra Konstantoulaki ${ }^{1}$, Ahmet Yigitbas $^{1}$, Apostolos Giovanis ${ }^{2}$ and \\ Ioannis Rizomyliotis ${ }^{3}$ \\ ${ }^{1}$ University of Westminster, 35 Marylebone Rd, London NW1 5LS, UK \\ ${ }^{2}$ University of West Attica, Ag.Spiridonos, 12210, Aigaleo, Athens, Greece \\ ${ }^{3}$ University of Brighton,Mithras House, Lewes Road, Brighton BN2 4AT, UK \\ K.Konstantoulaki@westminster.ac.uk
}

\begin{abstract}
The purpose of this paper is to investigate consumers' attitudes and behavioural intentions towards corporate social responsibility (CSR) practices in the airline industry by exploring the role of consumers' perceived values and expectations towards CSR initiatives in the airline industry. Data collected from airline industry customers, were used to empirically test the role of consumer values and expectations in relation to the attitudes and behavioural intentions towards CSR initiatives. Results indicate that consumer perceptions of value dimensions and CSR expectations have a significant positive effect on customer attitudes when purchasing services in the airline industry. Results also indicate that customer attitudes have a significant positive relationship with consumers' purchase intentions in the airline industry. The paper offers valuable insights to airline company managers with on how CSR initiatives can be used towards increasing companies' value proposition.
\end{abstract}

Keywords: CSR expectations, Airline Industry, perceived value

\section{Introduction}

The context of Corporate Social Responsibility (CSR) has been argued over 50 years, and it has never been this vital for companies even before this time [1]. Also, consumer support for CSR is well established and companies are now expected to engage in some form of CSR [2]. Over the last 25 years, consumers have become much more aware of the environmental issues caused by human activity [3]. There is a growing interest towards companies that in relation to their social responsibility whilst doing business [2]. Tourism sector has received a significant attention at this point that while providing economic and social benefits to the society, it also has negative impacts socially, economically and environmentally [3]. As the industry is expected to grow significantly, pressure on the companies within the sector for socially responsible tactics is also increasing [4]. Within the tourism sector, airline industry has at- 
tracted consumers' attention in relation to socially responsible tactics within its businesses [3]. For this reason, there is a growing interest among the society towards the Corporate Social Responsibility (CSR) initiatives within the airline industry and companies are now expected to engage in some form of CSR [5].

CSR literature, suggests that expectations and values are important factors for understanding consumers' behaviours towards socially responsible companies and their CSR initiatives. Consumers' evaluation of CSR initiatives can be related to consumers' expectations; consumer's expectations on CSR initiatives are one of the variables that affect society's opinion about companies [6], [7]. In addition, literature suggests that consumers' behaviours may be dependent on the value they receive from a specific service/ product [8], [9], [10]. However, none of the studies has explicitly measured consumers' perceived values and expectations from CSR within the airline industry [10]. For this reason, the current study focuses on the consumers' attitudes and behavioural intentions in order to underpin the reasoning behind the consumer behaviour towards CSR initiatives in the airline industry. The roles of values and expectations have examined in order to explore both attitudes and behavioural intentions of the airline industry consumers.

\section{Theoretical Background}

Although CSR importance is increasing, there is still no clear identification for CSR in the literature [11], [12]. The reason can be the unclear boundaries and debatable legitimacy, or different definitions and unidentified corporate benefit of it [13]. Among the dispute about the CSR and its borders, Carroll's [14] four-part model of CSR (The Pyramid of CSR) is a widely accepted approach [1], [15], [16], [17], [18], [19], [20], [21], [22], [23], [24], [25], [26]. Although many researchers have used Carroll's [14] four categories of CSR in the past, it still carries some weaknesses that identified by Schwartz and Carroll [27]. However, because of its incomplete structure and the increasing need to provide better and much clearer definition for the four-part approach, Schwartz and Carroll [27] provided a revised version of the pyramid of CSR by Carroll [14]: The Three-Domain Model of CSR. The three-domain model consists of 3 domains (Economic, Legal, and Ethical) which, in total, include 7 subcategories: (i) purely economic, (ii) purely legal, (iii) purely ethical, (iv) economic/ethical, (v) economic/legal, (vi) legal/ethical, (vii) economic/legal/ethical [27]. The current study employs the revised Three-Domain Model [27], to empirically investigate CSR and its relationship with consumer attitude and purchase intentions in airline industry.

\subsection{CSR Initiatives in Airline Industry}

There is a growing interest towards CSR initiatives in the airline industry in order to decrease the negative effects of the industry and contribute to sustainable development [3], [25]. However, there isn't enough number of studies that explore CSR practice in the airline industry, and additionally the industry's adaptation of CSR has been relatively slower compared to the one in other industries [5] and it is still considered 
very limited [4]. Most of the studies towards CSR initiatives in airline industry focus on specific case studies [4], environmental management or limited aspects of CSR [25] and tend to have a limited depth in order to provide an overview towards the CSR initiatives in airline industry.

\subsection{Consumers' Perceived Value Dimensions and CSR initiatives}

In the marketing literature, perceived value has been identified as one of the most important measures for gaining competitive edge [28] and it has been argued to be the most vital indicator of purchase intentions. However, in the leisure and tourism services, including the airline industry, attitudes, purchase intentions and consumer loyalty are usually forecasted by measuring consumer satisfaction and/or service quality [29]. Woodruff [30] concluded that, perceived value that underlines customer evaluation has to be taken in to consideration in order to forecast consumer attitudes and purchase intentions. Some studies suggest that the value consumers receive from CSR is variable [10] and consumer behaviour may be dependent on the value they receive [6], [8], [9], [10].

Prior studies in the literature also agree that consumer perceived value is an important pointer of the purchase intentions and attitudes [30], [31], [30], [29]. Since consumer perceived value has been found to be an important pointer of purchase intentions and attitudes, consumers' perceived values need to be examined in order to understand consumer attitudes and behaviour intentions towards CSR initiatives in airline industry. Seth et al. [32] suggest 5 different dimensions: (a) social, (b) emotional, (c) functional, (d) epistemic and (e) conditional value, regarding purchase decision at a product level or at a brand level. Their work gives the most useful foundation in the literature for extending existing value constructs since it was also validated in many fields including economics, social and clinical psychology [33]. Based on Seth et al. [32] framework for values, Green and Peloza [10] argued that CSR could provide 3 types of values for the customers; emotional value, social value and functional value: (a) emotional value is received when a consumer buys a product/ service that incorporate social or environmental attributes; (b) social value occurs from purchases related to companies that are applying CSR initiatives. This is due to the fact that people are making judgments about each other on the basis of their purchases and lastly, and (c) functional value, which is the benefit that consumers receive from the actual product or service that has been purchased.

\subsection{Consumers' Expectations of CSR Initiatives}

Expectations are playing an essential role in many types of consumer decisions (Creyer, 1997) ${ }^{6}$ and they are linked with CSR [7]. In the last decade, CSR issues have become a major driver for society's opinion [34] and as Creyer [6], consumers form expectations about the ethicality of corporate behaviour. Expectations towards CSR initiatives are increasing and consumers are intolerant towards companies, which are failing to do their obligations [34]. The evaluation of CSR initiatives by consumers can be defined via the consumer expectations [34], since the consumer expectations 
are one of the variables that affect society's attitudes about companies [6], [7]. Consumers' expectations of CSR represent the minimum level of CSR initiatives that companies are expected to apply. On the other hand, recent studies suggest that consumer beliefs and expectations of CSR actually form consumer responses towards corporate behaviour [6], [7]. Consumer beliefs and expectations of CSR actually form the consumer responses towards corporate behaviour [6], [7]. In addition, consumers tend to project their expectations and concerns into their behaviour towards companies [35], [36]. Specifically, consumer expectations towards CSR initiatives significantly impact the consumer behaviour towards the companies [6], [37].

\subsection{Consumer Attitudes, Behavioural Intentions and CSR Initiatives}

Many studies support a positive relationship between CSR and consumer attitudes along with positive affective, cognitive and behavioural responses [38], [39], [40]. Also, it is suggested that some consumers pursue purchases based on company's engagement with CSR initiatives. Consumers have a supportive attitude towards companies which are involved in CSR initiatives and/or companies that are well known to have higher level of support and connection with the community. On the other hand, some studies suggest that CSR applications are not accepted easily by consumers and that the consequences (reward or punishment towards the company) when involving in CSR initiatives are still unknown [41], [6], [42]. Finally, some studies suggest that consumers punish the firms that are not considered sincere [42]. This inconsistency might be due to the fact that there is a significant range of consumer reactions and different ways to develop attitudes when it comes to CSR initiatives [10]. Thus, it also makes sense that different attitudes evoke variance in behavioural intentions, which could lead to important implications for the companies engaging in CSR initiatives.

As Green and Peloza [10] suggest, consumers assess how companies' CSR behaviour matches their own values, morals, standards, expectations and priorities and how CSR initiatives can add extra value to their purchase. In sum, following what is written in existing literature on the CSR practices, the consumers' expectations and perceived value of CSR related services, and in relation to their behaviour, this study aims to offer new knowledge and data in a quite neglected area, the airline industry. For this purpose, the following hypotheses are proposed:

H1: Consumers' perception of value dimensions when purchasing services involving CSR initiatives positively affect consumers' attitudes towards CSR initiatives in the airline industry.

H2: Consumer expectations from CSR initiatives in the airline industry positively affect consumers' attitudes towards CSR initiatives in the airline industry.

H3: Consumers' attitudes towards CSR initiatives in the airline industry positively affect consumers' purchase intentions towards services involving CSR initiatives in the airline industry. 


\section{$3 \quad$ Methodology and Results}

A conclusive research design was selected in order to examine the relationships described in the conceptual framework. Convenience sampling was employed and an online questionnaire was developed and distributed via the social networks; 201 respondents agreed to participate. The sample consisted of $41.3 \%$ male and $58.7 \%$ female, similar to the gender structure of the airline industry customers [26]. The questionnaire was pretested in order to increase the validity and reliability and a pilot survey was conducted. The scale proposed by Kolodinsky et al. [43] was adopted to measure attitudes towards CSR in airline industry while the PERVAL scale [44] was used to measure the three consumer perceived value elements (functional, social and emotional), which can be gained via CSR initiatives [10]. The scale for measuring expectations towards CSR initiatives in airline industry was taken from [6] and purchase intention was measured with the use of the scale taken from David et al. [45] study. All variables where measured on 7-point scales ranging from "Strongly Disagree" (1) to "Strongly Agree" (7).

All scales were proved to be reliable and internally consistent (Cronbach's alpha index) and the summated multi-item scales were constructed based on the mean scores [46]. Moreover, all measures were found to be unidimensional and valid in terms of both discriminant and convergent validity. To check the validity of our research hypotheses and the significance of all causal relationships of the model, we followed SEM analysis. According to the results (Table 1) there is a good fit of the hypothesized model to our data, and all hypotheses are accepted. Consistent with the previous findings, the significance tests for the path coefficients indicate a significant positive influence of all tested variables on Consumers' attitudes towards CSR initiatives. Moreover, the latter were found to positively affect customers' purchase intentions.

Table 1. Fit Indices and Path Coefficients

\begin{tabular}{lcccc}
\hline Path Model & CFI $=0.90$, RMSEA=0.07 & Std. Beta & t-value & Sig. \\
& & & & \\
\hline $\mathrm{PV} \rightarrow \mathrm{CA}$ & 0.13 & 4.33 & $<0.05$ \\
$\mathrm{CE} \rightarrow \mathrm{CA}$ & 0.09 & 2.25 & $<0.05$ \\
$\mathrm{CA} \rightarrow$ PI & 0.52 & 3.14 & $<0.05$ \\
\hline Note: Customer Perception of Value (PV); Customer Attitude (CA); Purchase Intentions (PI)
\end{tabular}

\section{Discussion}

Even though there is a growing interest, there still aren't enough studies on CSR practices in the airline industry [4] [5]. Also, the studies towards CSR initiatives in airline industry have a limited depth and are insufficient to provide an overview towards the CSR initiatives in airline industry [3]. This study contributes to the marketing litera- 
ture by providing an insight to the consumers' attitudes and purchase intentions towards CSR practices in the airline industry via examining consumer perceived values and expectations. To begin with, this study revealed that the CSR practices in the airline industry increases the perceived quality of the airline companies, and it supports the idea that CSR initiatives is a useful tool for marketing tactics that aim to increase the perceived value of the airline companies. Moreover, data analysis revealed that there is a positive between consumers' attitudes towards CSR initiatives in the airline industry and consumers' purchase intentions in relation to services involving CSR initiatives in the airline industry. The results were consistent with the existing literature [47], [48], [49], and stressed out the role of attitudes as a significant predictor of purchase intentions within the airline industry. Expectations were also found to be a significant predictor of attitudes towards the companies with CSR initiatives in the airline industry. Airline companies can benefit from market research in order to thoroughly investigate consumers' profile and, thus, can determine the level of investment that is required in order to meet consumers' expectations. This can lead to the creation of favorable attitudes towards the company and, in turn, to increased purchase intentions. Advertising and promotion campaigns can also increase the perceived value of the consumers by focusing on the CSR initiatives of the company within the airline industry. Future research could be directed towards the CSR expectations research in the airline industry. Specifically, the development of a new scale to measure consumer expectations for CSR initiatives could in-crease the efficiency of measuring the expectations within airline industry.

\section{References}

1. Smith, W.J. and Wokutch, R.E. and Harrington, K.V. and Dennis, B.S.: An examination of the influence of diversity and stakeholder role on corporate social orientation. Business \& Society 40(3), 266-294 (2001).

2. Rundle-Thiele, S.Ball, K. and Gillespie, M.: Raising the bar: from corporate social responsibility to corporate social performance. Journal of Consumer Marketing 25(4), 24553 (2008).

3. Cowper-Smith, A. and de Grosbois, D.: The adoption of corporate social responsibility practices in the airline industry. Journal Of Sustainable Tourism 19(1), 59-77 (2011).

4. Tsai, W. H., Hsu, J. L.: Corporate social responsibility programs choice and costs assessment in the airline industry-A hybrid model. Journal of Air Transport Management 14(4), 188-196 (2008).

5. Lynes, J., Andrachuk, M.: Motivations for corporate social and environmental responsibility: A case study of Scandinavian Airlines. Journal Of International Management 14(4), 377-390 (2008).

6. Creyer, E.H.: The influence of firm behavior on purchase intention: do consumers really care about business ethics? Journal of Consumer Marketing 14(6), 421 - 432 (1997).

7. Podnar, K., Golob, U.: CSR expectations: the focus of corporate marketing. Corporate Communications: An International Journal 12(4), 326-340 (2007).

8. Menon, S., Kahn, B.: Corporate sponsorships of philanthropic activities: when do they impact perception of sponsor brand?. Journal of Consumer Psychology 13(3), 316-327 (2003). 
9. Peloza, J.: The challenge of measuring financial impacts from investments in corporate social performance. Journal of Management 35(6), 1518-1541 (2009).

10. Green, T., Peloza, J.: How does corporate social responsibility create value for consumers?. Journal Of Consumer Marketing 28(1), 48-56 (2011).

11. Carrigan, M., Attalla, A.: The myth of the ethical consumer: Do ethics matter in purchase behavior?. Journal of Consumer Marketing 18(7), 560-77. (2001).

12. Melo, T., Galan, J.: Effects of corporate social responsibility on brand value. Journal of Brand Management 18(6), 423-437 (2011).

13. Lantos, G.P.: The boundaries of strategic corporate social responsibility. Journal of Consumer Marketing 18(7), 595 - 632. (2001).

14. Carroll, A.B.: A three-dimensional conceptual model of corporate performance. Academy of Management Review 4(4), 497-505 (1979).

15. Wartick, S., Cochran, P.: The evolution of the corporate social performance model. Academy Of Management Review 10(4), 758-769 (1985).

16. Wood, D.J.: Corporate social performance revisited. Academy of Management Review 16(4), 691-718 (1991).

17. Swanson, D.L.: Addressing a theoretical problem by reorienting the corporate social performance model. Academy of Management Review 20(1), 43-64 (1995).

18. Swanson, D.L.: Toward an integrative theory of business and society: a research strategy for corporate social performance. Academy Of Management Review 24(3), 506-521 (1999).

19. Aupperle, K., Carroll, A.B., Hatfield, J.: An empirical examination of the relationship between corporate social responsibility and profitability. Academy Of Management Journal 28(2), 446-463 (1985)

20. Spencer, B., Butler, J.: Measuring the relative importances of social responsibility components: a decision modeling approach. Journal Of Business Ethics 6(7), 573-577 (1987).

21. O'Neill, H., Saunders, C., McCarthy, A.: Board Members, corporate social responsiveness and profitability: are tradeoffs necessary?. Journal Of Business Ethics 8(5), 353-357 (1989).

22. Strong, K., Mayer, G.: An integrative descriptive model for ethical decision making. Journal of Business Ethics 11(2), 89-94 (1992).

23. Ibrahim, N., Angelidis, J.: The corporate social responsiveness orientation of board members: are there differences between inside and outside directors? Journal Of Business Ethics 14(5), 405-410 (1995).

24. Burton, B., Hegarty, W.: Some determinants of student corporate social responsibility orientation. Business \& Society 38(2), 188-205 (1999).

25. Phillips, E.D.: Corporate social responsibility in aviation. Journal Of Air Transportation 11(1), 65-87 (2006).

26. Golob, U., Lah, M., Jančič, Z.: Value orientations and consumer expectations of corporate social responsibility. Journal of Marketing Communications 14(2), 83-96 (2008).

27. Schwartz, M., Carroll, A.B.: Corporate social responsibility: a three-domain approach. Business Ethics Quarterly 13(4), 503-530 (2003).

28. Parasuraman, A.A.: Reflections on gaining competitive advantage through customer value. Journal of The Academy Of Marketing Science 25(2), 154-161 (1997).

29. Petrick, J.F. An Examination of the Relationship between Golf Travelers' Satisfaction, Perceived Value and Loyalty and Their Intentions to Revisit. Dissertation, Clemson University, Clemson, SC (1999).

30. Woodruff, R.B.: "Customer value: the next source for competitive advantage. Journal of the Academy of Marketing Science 25(2), 139-153 (1997). 
31. Jayanti, R.K, Ghosh, A.K.: Service value determination: an integrative perspective. Journal of Hospitality \& Leisure Marketing 3(4), 5-25 (1996).

32. Sheth, J.N., Newman, B.I., Gross, B.L.: Why we buy what we buy: a theory of consumption values. Journal of Business Research 22(2), 159-170 (1991).

33. Sweeney, J.C., Soutar, G.N.: Consumer perceived value: the development of a multiple item scale. Journal of Retailing 77(2), 203-220 (2001).

34. Dawkins, J., Lewis, S.: CSR in stakeholders expectations: And their implication for company strategy. Journal of Business Ethics 44(2-3), 185-193 (2003).

35. Klein, J. G., Smith, N. C., John, A.: Exploring motivations for participation in a consumer boycott. In: Broniarczyk, S.M, Nakamoto, K. (eds.) NA - Advances in Consumer Research, Association for Consumer Research, vol. 29, 363-369, Valdosta, GA (2002).

36. Maignan, I., Ferrell, O. C., Ferrell, L.: A stakeholder model for implementing social responsibility in marketing. European Journal of Marketing 39(9/10), 956-977 (2005).

37. Nebenzahl, I. D., Jaffe, E. D., Kavak, B.: Consumers' punishment and rewarding process via purchasing behavior. Teaching Business Ethics 5(3), 283-305 (2001).

38. Murray, K.B., Vogel, C.M.: Using a hierarchy-of-effects approach to gauge the effectiveness of corporate social responsibility to generate goodwill toward the firm: Financial versus nonfinancial impacts. Journal of Business Research 38(2), 141-159 (1997).

39. Folkes, V.S., Kamins, M.A.: Effects of information about firms' ethical and unethical actions on consumers' attitudes. Journal of Consumer Psychology 8(3), 243-259 (1999).

40. Ellen, P.S., Mohr, L.A., Webb, D.J.: Charitable programs and the retailer: do they mix?. Journal of Retailing 76(3), 393-406 (2000).

41. Brown, T., Dacin, P.: The company and the product: corporate associations and consumer product responses. Journal of Marketing 61(1), 68-84 (1997).

42. Becker-Olsen, K., Cudmore, B, Hill, R.: The impact of perceived corporate social responsibility on consumer behavior. Journal Of Business Research 59(1), 46-53 (2006).

43. Kolodinsky, R.W., Madden, T.M., Zisk, D.S., Henkel, E.T.: Attitudes about corporate social responsibility: business student predictors. Journal of Business Ethics 91(2), 167-181 (2010).

44. Lee, D., Trail, G. T., Kwon, H. H., Anderson, D. F.: Consumer values versus perceived product attributes: Relationships among items from the MVS, PRS, and PERVAL scales. Sport Management Review 14(1), 89-101 (2011).

45. David, P., Kline, S., Dai, Y.: Corporate social responsibility practices, corporate identity, and purchase intention: A dual-process model. Journal of Public Relations Research 17(3), 291-313 (2005).

46. Spector, P. E.: Summated rating scale construction: an introduction sage. Newbury Park, CA (1992).

47. Ajzen, I. The theory of planned behavior", Organizational Behavior and Human Decision Processes 50(2), 179-211 (1991).

48. Alwitt, L., Pitts, R. Predicting purchase intentions for an environmentally sensitive product. Journal of Consumer Psychology 5(1), 49-64. (1996).

49. Coleman, L., Bahnan, N., Kelkar, M., Curry, N. Walking the walk: how the theory of reasoned action explains adult and student intentions to go green", Journal Of Applied Business Research 27(3), 107-116 (2011). 
UNIVERSITY OF WEST ATTICA

\section{CAMPUS 1}

Address : : Agiou Spiridonos Str., 122 10, Egaleo, Athens

Tel. : $\quad$ : $\quad$ 30 2105385209

Egaleo: 9/10/2018

E-mail : nkavoura@teiath.gr

TO: -

Dr Apostolos Giovanis

To whom it may concern,

This is to certify that the paper titled

Understanding Consumers' Attitudes and Behavioural Intentions towards Corporate Social Responsibility in the Airline Industry: The Role of Perceived Value and Expectations

submitted by:

Kleopatra Konstantoulaki ${ }^{1}$, Ahmet Yigitbas $^{1}$, Apostolos Giovanis ${ }^{2}$ and Ioannis Rizomyliotis $^{3}$

${ }^{1}$ University of Westminster, 35 Marylebone Rd, London NW1 5LS, UK

${ }^{2}$ University of West Attica, Ag.Spiridonos, 12210, Aigaleo, Athens, Greece

${ }^{3}$ University of Brighton,Mithras House, Lewes Road, Brighton BN2 4AT, UK

after double blind review, has been approved for presentation at ICSIMAT

The Work will be published in the book series [Springer Proceedings in Business and Economics].

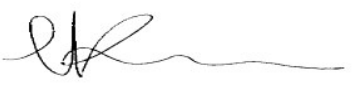




\title{
Consent to Publish for Conference Proceedings
}

\author{
Title of Book/Volume/Conference (hereinafter called “Work): Strategic Innovative Marketing and \\ Tourism - 7th ICSIMAT, Athens, Greece, 2018
}

\author{
Editor(s) name(s) (hereinafter called "Editor"): Prof. Androniki Kavoura, Prof. Efstathios \\ Kefallonitis, Prof. Apostolos Giovanis \\ Title of the conference paper (hereinafter called “Contribution"): Understanding Consumers' Attitudes and \\ Behavioural Intentions towards Corporate Social Responsibility in the Airline Industry: The Role of Perceived Value and Expectations
}

Author(s) full name(s) (hereinafter jointly called “Author”): Kleopatra Konstantoulaki, Ahmet Yigitbas, Apostolos Giovanis and loannis Rizomyliotis

Corresponding author's name, address, affiliation and e-mail: Kleopatra Konstantoulaki, University of Westminster, 35 Marylebone Rd, London NW1 5LS, UK, K.Konstantoulaki@westminster.ac.uk

When Author is more than one person the expression "Author" as used in this agreement will apply collectively unless otherwise indicated.

The Publisher intends to publish the Work under the imprint Springer. The Work may be published in the book series [Springer Proceedings in Business and Economics].

\section{$\S 1$ Rights Granted}

Author hereby grants to Springer International Publishing AG (hereinafter called "Publisher") the exclusive, sole, permanent, world-wide, transferable, sub-licensable and unlimited right to reproduce, publish, distribute, transmit, make available or otherwise communicate to the public, translate, publicly perform, archive, store, lease or lend and sell the Contribution or parts thereof individually or together with other works in any language, in all revisions and versions (including soft cover, book club and collected editions, anthologies, advance printing, reprints or print to order, microfilm editions, audiograms and videograms), in all forms and media of expression including in electronic form (including offline and online use, push or pull technologies, use in databases and data networks (e.g. Internet) for display, print and storing on any and all stationary or portable end-user devices, e.g. text readers, audio, video or interactive devices, and for use in multimedia or interactive versions as well as for the display or transmission of the works or parts thereof in data networks or search engines, and posting the Contribution on social media accounts closely related to the Work, as well as using the Contribution for training purposes, such as but not limited to massive open online courses), in whole, in part or in abridged form, in each case as now known or developed in the future, including the right to grant further timelimited or permanent rights. Publisher especially has the right to permit others to use individual illustrations, tables or text quotations and may use the Contribution for advertising purposes. For the purposes of use in electronic forms, Publisher may adjust the Contribution to the respective form of use and include links (e.g. frames or inline-links) or otherwise combine it with other works and/or remove links or combinations with other works provided in the Contribution. For the avoidance of doubt, all provisions of this contract apply regardless of whether the Contribution or the Work itself constitutes a database under applicable copyright laws or not.

The copyright in the Contribution shall be vested in the name of Publisher. Author has asserted his/her right(s) to be identified as the originator of this Contribution in all editions and versions of the Work and parts thereof, published in all forms and media. Publisher may take, either in its own name or in that of Author, any necessary steps to protect the rights granted under this Agreement against infringement by third parties. It will have a copyright notice inserted into all editions of the Work and on the Contribution according to the provisions of the Universal Copyright Convention (UCC).

The parties acknowledge that there may be no basis for claim of copyright in the United States to a Contribution prepared by an officer or employee of the United States government as part of that person's official duties. If the Contribution was performed under a United States government contract, but Author is not a United States government employee, Publisher grants the United States government royalty-free permission to reproduce all or part of the Contribution and to authorise others to do so for United States government purposes. If the Contribution was prepared or published by or under the direction or control of the Crown (i.e., the constitutional monarch of the Commonwealth realm) or any Crown government 
department, the copyright in the Contribution shall, subject to any agreement with Author, belong to the Crown. If Author is an officer or employee of the United States government or of the Crown, reference will be made to this status on the signature page.

\section{$\S 2$ Rights retained by Author}

Author is permitted to self-archive a pre-print and an author's accepted manuscript version of the Contribution.

a) A pre-print is the Author's first version of the manuscript submitted to the Publisher ("Pre-Print"). Prior to acceptance for publication, Author retains the right to make a Pre-Print of the Contribution available on any of the following: his/her own personal, self- maintained website; a legally compliant, non-commercial pre-print server such as but not limited to arXiv and bioRxiv.

Once the Contribution has been published, Author should update the acknowledgement and provide a link to the definitive version on the publisher's website: "This is a pre-print of a contribution published in [insert title of book and name(s) of Editor(s)] published by [insert name of Publisher]. The final authenticated version is available online at: https://doi.org/[insert DOI]".

b) An Author's Accepted Manuscript ("AAM") is the version accepted by the Publisher for publication, but prior to copyediting and typesetting, that can be made available under the following conditions:

i. Author retains the right to make an AAM of the Contribution available on their own personal, self- maintained website immediately on acceptance,

ii. Author retains the right to make an AAM of the Contribution available for public release on any of the following, 12 months after first publication ("Embargo Period"): their employer's internal website; their institutional and/or funder repositories and all services offering organized, legally compliant central archiving, including social scientific networks. AAMs may also be deposited in such repositories immediately on acceptance, provided that they are not made publicly available until after the Embargo Period.

An acknowledgement in the following form should be included, together with a link to the published version on the publisher's website: "This is a pre-copyedited version of a contribution published in [insert title of book and name(s) of Editor(s)] published by [insert name of Publisher]. The definitive authenticated version is available online via https://doi.org/[insert DOI]".

The DOI (Digital Object Identifier) can be found at the bottom of the first page of the published Contribution.

For the avoidance of doubt Author shall not use the publisher's final published version (in pdf or html/xml format) for the purpose of the above described self-archiving.

Additionally, Author retains, in addition to uses permitted by law, the right to communicate the content of the Contribution to other research colleagues, to share the Contribution with them in manuscript form, to perform or present the Contribution or to use the content for non-commercial internal and educational purposes, provided the original source of publication is cited according to current citation standards.

\section{$\S 3$ Warranties}

Author agrees, at the request of Publisher, to execute all documents and do all things reasonably required by Publisher in order to confer to Publisher all rights intended to be granted under this Agreement. Author warrants that the Contribution is original except for such excerpts from copyrighted works (including illustrations, tables, animations and text quotations) as may be included with the permission of the copyright holder thereof, in which case(s) Author is required to obtain written permission to the extent necessary and to indicate the precise sources of the excerpts in the manuscript. Third Party Material (including without limitation quotations, photographs, pictures, diagrams, drawings, tables, graphs or maps, and whether reproduced from print or electronic or other sources) may only be included in the Contribution with the prior agreement of the Publisher. In this case the Author must obtain (at the Author's expense) all necessary permissions to enable the Publisher to use the Third Party Material in the Contribution and shall provide the Editor of the Work and the Publisher with: (i) copies of all such permissions, and (ii) sufficient information to enable the Publisher to make appropriate acknowledgements.

Author warrants that Author is entitled to grant the rights in accordance with Clause 1 "Rights Granted", that Author has not assigned such rights to third parties, that the Contribution has not heretofore been published in whole or in part, that the Contribution contains no libellous or defamatory statements and does not infringe on any copyright, trademark, patent, statutory right or proprietary right of others, including rights obtained through licences; and that Author will indemnify Publisher against any costs, expenses or damages for which Publisher may become liable as a result of any claim which, if true, would 
constitute a breach by Author of any of Author's representations or warranties in this Agreement. Author agrees to amend the Contribution to remove any potential obscenity, defamation, libel, malicious falsehood or otherwise unlawful part(s) identified at any time. Any such removal or alteration shall not affect the warranty and indemnity given by Author in this Agreement.

\section{$\S 4$ Delivery of Contribution and Publication}

Author shall deliver the Contribution to the responsible Editor of the Work on a date to be agreed upon, electronically in Microsoft Word format or in such form as may be agreed in writing with Publisher. The Contribution shall be in a form acceptable to the Publisher (acting reasonably) and in line with the instructions contained in the guidelines and Author shall provide at the same time, or earlier if the Publisher reasonably requests, any editorial, publicity or other form required by the Publisher.

Publisher will undertake the publication and distribution of the Work in print and electronic form at its own expense and risk within a reasonable time after it has given notice of its acceptance of the Work to Author in writing.

\section{$\S 5$ Author's Discount for Books and Electronic Access}

Author may obtain copies of the Work for personal use at a discount of $40 \%$ off the list-price if ordered directly from Publisher. Furthermore, Author is entitled to purchase for his/her personal use (directly from Publisher) other books published by Publisher at a discount of $40 \%$ off the list price for as long as there is a contractual arrangement between Author and Publisher and subject to applicable book price regulation. Resale of such copies is not permitted.

Publisher shall provide electronic access to the electronic final published version of the Work on Publisher's Internet portal, currently known as springer.com and/or palgrave.com, to Author, provided Author has included his/her email address in the manuscript of the Work. Furthermore, Author has the right to download and disseminate single contributions from the electronic final published version of the Work for his/her private and professional non-commercial research and classroom use (e.g. sharing the contribution by mail or in hard copy form with research colleagues for their professional non-commercial research and classroom use, or to use it for presentations or handouts for students). Author is also entitled to use single contributions for the further development of his/her scientific career (e.g. by copying and attaching contributions to an electronic or hard copy job or grant application).

When Author is more than one person each of the co-authors may share single contributions of the Work with other scientists or research colleagues as described above. In each case, Publisher grants the rights to Author under this clause provided that Author has obtained the prior consent of any co-author(s) of the respective contribution.

\section{$\S 6$ Termination}

Either party shall be entitled to terminate this Agreement forthwith by notice in writing to the other party if the other party commits a material breach of the terms of the Agreement which cannot be remedied or, if such breach can be remedied, fails to remedy such breach within 28 days of being given written notice to do so.

On termination of this Agreement in accordance with its terms, all rights and obligations of Publisher and Author under this Agreement will cease immediately, except that any terms of this Agreement that expressly or by implication survive termination of this Agreement shall remain in full force and effect.

\section{$\S 7$ Governing Law and Jurisdiction}

If any difference shall arise between Author and Publisher concerning the meaning of this Agreement or the rights and liabilities of the parties, the parties shall engage in good faith discussions to attempt to seek a mutually satisfactory resolution of the dispute. This agreement shall be governed by, and shall be construed in accordance with, the laws of Switzerland. The courts of Zug, Switzerland shall have the exclusive jurisdiction. 
Corresponding Author signs for and accepts responsibility for releasing this material on behalf of any and all CoAuthors.

\section{Signature of Corresponding Author:}

Date:

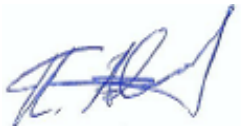

$09 / 11 / 2018$

I'm an employee of the US Government and transfer the rights to the extent transferable (Title 17 §105 U.S.C. applies)

$\square \mathrm{I}$ 'm an employee of the Crown and copyright on the Contribution belongs to the Crown

For internal use only:

Order Number: 86989872

GPU/PD/PS: 5/50/559

Legal Entity Number: 1128 Springer International Publishing AG

Springer-C-CTP-05/2018 